\title{
ASPECTOS CULTURALES, SOCIALES Y PRODUCTIVOS PARA UNA TIPOLOGÍA DE CAFETICULTORES
}

\author{
CULTURAL, SOCIAL AND PRODUCTIVE ASPECTS USED FOR A \\ TYPOLOGY OF COFFEE PRODUCERS
}

\author{
Verónica Rosales-Martínez ${ }^{1}$, J. Pablo Martínez-Dávila ${ }^{{ }^{*}}$, Francisco Osorio-Acosta ${ }^{1}$, \\ Gustavo López-Romero ${ }^{1}$, Alberto Asiaín-Hoyos ${ }^{1}$, Néstor Estrella-Chulím ${ }^{2}$
}

\begin{abstract}
${ }^{1}$ Programa de postgrado en Agroecosistemas Tropicales. Colegio de Postgraduados, Campus Veracruz. Km. 88.5 Carretera Federal Xalapa-Ver., Tepetates, Manlio Fabio Altamirano, Veracruz, México.91690.vrosales@colpos.mx, jpmartin@colpos.mx, fosorioa@colpos.mx, glromero@ colpos.mx, aasiain@colpos.mx. ${ }^{2}$ Colegio de Postgraduados Campus Puebla, Km. 125.5. Carr. Fed. México-Puebla, Momoxpan, Pue.72760.nestrela@colpos.mx.
\end{abstract}

\section{RESUMEN}

El objetivo de esta investigación fue generar una tipología de productores cafetaleros con base en variables de tipo social, cultural, económico y productivo para determinar las diferencias existentes entre ellos y ofrecer información a las instancias gubernamentales para que diseñen estrategias en pro del mejoramiento de la calidad de vida de los pobladores. Se aplicó una encuesta a 145 productores cafetaleros en 2014, en el Distrito 005 de Fortín, Veracruz. Los resultados mostraron que los productores se clasifican en tres tipos: de subsistencia, transicionales y empresariales. Los de tipo empresarial son los que poseen mayor nivel tecnológico, mayor superficie, mayor ingreso capitalizable, mayor número de cortadores con pago, en comparación con los de subsistencia y transicionales. Por su carácter tradicional, el cultivo del café en este Distrito ha representado una opción de subsistencia y reproducción, más que social o de acumulación de riquezas o de capital con alta productividad económica.

Palabras clave: agroecosistemas, café, productores, tipología.

\section{INTRODUCCIÓN}

$\mathrm{E}$ n México el cultivo de café se realiza principalmente en cuatro estados de la República Mexicana: Chiapas (35\%), Veracruz (25\%), Puebla (15\%) y Oaxaca (13\%), en los cuales se concentra $88 \%$ del total de la superficie nacional (781 $016 \mathrm{ha}$ ). La variedad de prácticas productivas en las fincas se relaciona con los modos específicos

* Autor responsable * Author for correspondence.

Recibido: septiembre, 2015. Aprobado: noviembre, 2016.

Publicado como ARTÍCULO en ASyD 15: 47-61. 2018.

\section{Abstract}

The objective of this study was to generate a typology of coffee producers based on variables of social, cultural, economic and productive type to determine the differences there are between them and to offer information to government instances in order to design strategies in pro of improvement of the quality of life of inhabitants. A survey was applied to 145 coffee producers in 2014, in District 005 of Fortín, Veracruz. The results showed that producers are classified into three types: subsistence, transitional and entrepreneurial. The entrepreneurial type are the ones that have the highest technological level, greater surface, highest capitalized income, highest number of paid cutters, in comparison with those of subsistence and transitional. Because of its traditional nature, coffee growing has represented an option for subsistence and reproduction in this District, rather than social or for wealth or capital accumulation with high economic productivity.

Key words: agroecosystems, coffee, producers, typology.

\section{INTRODUCTION}

$\mathrm{I}$ n México, coffee production is carried out primarily in four states of the Mexican Republic: Chiapas (35\%), Veracruz (25\%), Puebla $(15 \%)$ and Oaxaca $(13 \%)$, in which $88 \%$ of the total national surface (781 $016 \mathrm{ha})$ is concentrated. The variety of productive practices in plantations is related to the specific ways of conceiving coffee, where the manners of thought and practice have been built socially within the framework of a social-historical, local and regional context, from the experience and 
de concebir el café, donde las formas de pensamiento y de práctica se han ido construyendo socialmente en el marco de un contexto histórico-social, local y regional, a partir de la experiencia y la posición de los productores en la cadena productiva (Ejea, 2009).

De esta manera, al campesinado no se le debe considerar como un conjunto homogéneo al cual se le puedan proponer "paquetes tecnológicos" uniformes. Para ello se proponen las tipologías de productores. Las enfocadas en las actividades agrícolas consideran variables, como tamaño del predio, asistencia técnica, factores de productividad, crédito, rasgos de producción, ingresos y nivel de educación. Otros aspectos socioeconómicos como edad y nivel de desarrollo socioeconómico (Gabriel, 2003), destino de la producción, lugar de residencia, ingresos extraprediales, ingresos netos, mano de obra familiar, empleo de mano de obra complementaria (Soverna et al., 2008), porcentaje de autoconsumo, nivel tecnológico, ingreso capitalizable y mano de obra familiar sin pago (CEPAL, 1989), superficie total, número de empleos fijos, número de empleos temporales, tiempo dedicado a la producción (Contreras, 2010), manejo de la tierra, acceso a mercados, y uso de mano de obra (Madariaga, 2001).

Asimismo, los grupos y tipos sociales se construyen observando la realidad tan compleja y determinando las distintas categorías y características de la realidad observada. Estos son entes vivos, concretos y creativos integrados por individuos que: se comunican, interactúan, se estructuran o desestructuran en procesos organizacionales; desarrollan y perfeccionan sus capacidades para actuar organizadamente en procura de metas comunes (Bolaños, 1999). Generalmente, la tipificación es un trabajo sencillo y de utilidad práctica para promover acciones de organización y desarrollo de los productores (Vázquez et al., 2009). La elección de este método de tipificación se fundamenta en que la actividad agrícola se practica en áreas con diversas condiciones naturales y sociales a lo largo del territorio (Gabriel, 2003).

Así, la construcción de tipologías ha sido una preocupación central entre los analistas del agro mexicano. No obstante, estas tipologías son de carácter economicista o productivista, con ausencia de variables ambientales y culturales, sin considerar los factores naturales, lo que hace que las tipologías no cuenten con una representatividad espacial y una identidad (Toledo et al., 2002). position of producers in the productive chain (Ejea, 2009).

Therefore, peasants should not be considered as a homogeneous group to which uniform "technological packages" can be proposed. For this purpose, typologies of producers are proposed. Those focused on agricultural activities consider variables such as size of the plot, technical assistance, productivity factors, credit, production features, earnings and level of education. Other socioeconomic aspects like age and level of socioeconomic development (Gabriel, 2003), destination of the production, place of residence, extra-plot income, net income, family workforce, employment of complementary workforce (Soverna et al., 2008), percentage of auto-consumption, technological level, capitalized income, and family workforce without payment (CEPAL, 1989), total surface, number of fixed jobs, number of temporary jobs, time devoted to production (Contreras, 2010), land management, access to markets, and use of labor (Madariaga, 2001).

Likewise, the groups and social types are built by observing such a complex reality and defining the different categories and characteristics of the reality observed. These are living beings, concrete and creative, integrated by individuals who: communicate, interact, are structured or destructured in organizational processes; they develop and perfect their capacities to act in an organized manner in order to attain common goals (Bolaños, 1999). Generally, typification is simple work of practical use, to promote producers' organization and development actions (Vázquez et al., 2009). The choice of this method of typification is based on the fact that agricultural activity is practiced in areas with various natural and social conditions throughout the territory (Gabriel, 2003).

Thus, the construction of typologies has been a central preoccupation among analysts of the Mexican agricultural sector. However, these typologies are of economicist or productivist nature, with absence of environmental and cultural variables, without taking into consideration the natural factors, which make the typologies lack spatial representation and an identity (Toledo et al., 2002).

Therefore, this study seeks to generate a typology of producers, considering variables not just of socioeconomic and productive type, but also cultural; thus, identifying the characteristics 
Por lo anterior, esta investigación busca generar una tipología de productores, considerando variables no solo de tipo socioeconómico y productivo, sino también las de tipo cultural; de esta manera, identificar las características de la producción que permitan al productor mejorar su ingreso con las distintas formas de manejo a sus fincas, considerando aspectos como: ingreso capitalizable, superficie, nivel tecnológico y número de cortadores con pago para elaborar estrategias de desarrollo rural, tomando como base a la Ley de Desarrollo Rural Sustentable (2001) de México, la cual reconoce las diferencias y contradicciones que existen en el ámbito nacional entre los productores, necesitando generar una tipología de productores que apoye la definición de políticas públicas diferenciadas.

\section{Materiales y MéTodos}

\section{Área de estudio}

El área de estudio comprendió a 13 municipios del DDR 005 Fortín, Veracruz, México: Córdoba, Chocamán, Tepatlaxco, Tlaltetela, Comapa, Huatusco, Ixhuatlán del Café, Sochiapa, Tenampa, Tlacotepec de Mejía, Tomatlán, Totutla y Zentla. De estos municipios, Comapa, Huatusco, Zentla y Córdoba son los que cuentan con mayor extensión de unidades de producción (26 944.02 ha; 18580.96 ha; 15631.70 ha y 13838.79 ha; respectivamente). El principal uso de suelo es Agrícola, Pecuario, Industrial y Urbano (INEGI, 2009).

\section{Encuesta y análisis estadístico}

De acuerdo con el objetivo del estudio se diseñó un cuestionario para capturar, sistematizar y analizar los datos en forma sencilla, económica y oportuna. La fórmula de Scheaffer et al. (1987) generó una muestra de aproximadamente 200 productores de café en la región, a partir de una población de 63635 productores de acuerdo con el padrón cafetalero veracruzano, con una confiabilidad de $95 \%$ y precisión de $10 \%$. El tamaño de muestra se calculóde la siguiente manera:

$$
n=\frac{N s^{2}}{((N-1) D)+s^{2}}
$$

of production that allow the producer to improve his income with the different ways of managing their plantations, considering aspects such as: capitalized income, surface, technological level and number of paid cutters to elaborate strategies of rural development, taking as a basis the Sustainable Rural Development Law (2001) in México, which recognizes the differences and contradictions present in the national scope between producers, needing to generate a typology of producers that supports the definition of differentiated public policies.

\section{Materials ANd Methods}

\section{Study area}

The study area covered 13 municipalities in DDR 005 Fortín, Veracruz, México: Córdoba, Chocamán, Tepatlaxco, Tlaltetela, Comapa, Huatusco, Ixhuatlán del Café, Sochiapa, Tenampa, Tlacotepec de Mejía, Tomatlán, Totutla and Zentla. Of these municipalities, Comapa, Huatusco, Zentla and Córdoba are the ones with greatest expanse of production units (26944.02 ha; 18580.96 ha; 15631.70 ha and 13838.79 ha; respectively). The principal land use is Agricultural, Livestock, Industrial and Urban (INEGI, 2009).

\section{Statistical survey and analysis}

According to the objective of the study a questionnaire was designed to capture, systematize and analyze the data in a simple, economic and timely manner. The formula by Scheaffer et al. (1987) generated a sample of approximately 200 coffee producers in the region, from a population of 63635 producers based on the Veracruz coffee producers' census, with a reliability of $95 \%$ and accuracy of $10 \%$. The size of the sample was calculated in the following way:

$$
n=\frac{N s^{2}}{((N-1) D)+s^{2}}
$$

where: $n$ : sample size $N$ : population size $=63635$; Mean $=0.792$ ha; D: disposition of minimal error $=\mathrm{B}^{2} / 4 ; B: \bar{x}(10 \%)=0.792(0.10)=0.0792$ ha; $S^{2}$ : exploratory variance $=0.55^{2} \mathrm{ha}^{2}$ 
donde: $n$ : tamaño de muestra $N$ : tamaño de población $=63$ 635; Media $=0.792$ ha; D: disposición de error mínimo $=\mathrm{B}^{2} / 4 ; B: \bar{x}(10 \%)=0.792$ $(0.10)=0.0792$ ha; $S^{2}$ : varianza exploratoria $=0.55^{2}$ ha $^{2}$

Entonces una vez sustituida la fórmula, quedó de la siguiente manera:

$$
n=\frac{63635\left(0.55^{2}\right)}{63634 \frac{B^{2}}{4}+\left(0.55^{2}\right)}=192 \text { Entrevistas }
$$

Considerando los aspectos financieros, y debido a que la variabilidad de la información se reducía en función del incremento de la información de campo, se decidió entrevistar a 145 productores. La decisión se corresponde con el planteamiento de Scheaffer et al. (1987) de que sus modelos están construidos con $95 \%$ de confianza.

El cuestionario integró preguntas abiertas y cerradas; se aplicó durante los meses de junio a diciembre de 2014, para lo cual se requirió capacitar a encuestadores.

Específicamente, la tipificación fue construida con base en información de la CEPAL (1989). Se consideraron cuatro variables básicas que son: porcentaje de ingreso capitalizable (inversión), porcentaje de trabajo familiar sin pago, porcentaje del valor de la producción auto consumido y nivel tecnológico. La CEPAL (1989) propone esta tipología para el cultivo de maíz, y para efectos de esta tipología, el café en su mayoría, es cultivado con fines de comercialización y no de consumo, por lo que la variable básica de autoconsumo se sustituyó por la de superficie y la de número de cortadores con pago sustituyó a la de trabajo familiar sin pago, debido a que en el cultivo de café el corte incluye una de las actividades más importantes dentro del proceso de producción.

\section{Definición de variables}

Variable Ingreso Capitalizable. Es el dinero que ingresa por vender el café menos el utilizado en gastos de vivienda y de la finca. El gasto en la vivienda se calculó mediante la suma del porcentaje entre gastos de alimentación, salud, educación, e infraestructura
Then, once the formula is substituted, it was as follows:

$$
n=\frac{63635\left(0.55^{2}\right)}{63634 \frac{B^{2}}{4}+\left(0.55^{2}\right)}=192 \text { Entrevistas }
$$

Considering financial aspects, and because the variability of the information was reduced in function of the increase of field information, it was decided to interview 145 producers. The decision corresponds to the suggestion by Scheaffer et al. (1987) that their models are built with $95 \%$ confidence.

The questionnaire included open and closed questions; it was applied during the months of June to December 2014, for which there was a need to train pollsters.

Specifically, the typification was built on the basis of information from CEPAL (1989). Four basic variables were considered, which are: percentage of capitalized income (investment), percentage of family work without payment, percentage of autoconsumed production value, and technological level. The ECLAC (CEPAL, 1989) proposes this typology for maize cultivation, and for the purpose of this typology, coffee is mostly cultivated with the aim of commercialization and not consumption, which is why the basic variable of auto-consumption was substituted by that of surface and the number of paid cutters substituted unpaid family work, because in coffee cultivation cutting includes one of the most important activities within the production process.

\section{Definition of variables}

Capitalized Income Variable. It is the incoming money from selling coffee minus the money used in household and plantation expenses. The expenditure on the household was calculated through the sum of the percentage between expenses in food, health, education and infrastructure of the household. The total expenditure in the plantation was calculated through the sum of expenses in fertilization, cleaning, pruning, resowing, cutting and payment for product transport, and it is calculated in pesos.

Then, the variable Capitalized Income was calculated through the equation: 
de vivienda. El gasto total en la finca se calculó mediante la suma de los gastos de fertilización, limpia, poda, resiembra, corte y pago por transportar el producto y se calcula en pesos.

Entonces, la variable Ingreso Capitalizable se calculó mediante la ecuación:

$I C=I T-G V+G F$

donde IT: Ingreso Total, GV: Gastos en Vivienda, GF: Gastos en la Finca.

Variable Índice Tecnológico. Se obtuvo de la suma de las prácticas realizadas de limpia, fertilización, ahoyado, poda, regulación de sombra, prácticas de conservación de suelo y venta. Para su cálculo se consideró la siguiente ecuación:

\section{$I T=L I+F E+A H+P O+R S+P C S+V E$}

donde Limpia $(L I)$ : chapeo con machete, con azadón, con chapeadora y con líquido. Fertilización $(F E)$ : orgánica, química y cal. Ahoyado $(A H)$ : cavahoyos, barreno, barreta, tlalacha, cavador, pico, azadón, pala, zapa y coa. Poda $(P O)$ : machete, motosierra, serrote, tijera y gancho. Regulación de sombra $(R S)$ : siembra árboles, poda, tumba árboles secos, tumba árboles, siembra inga jinicuil y nacen solos. Prácticas de conservación de suelo (PCS): chapeo no al ras, siembra zacate de cańa, no utiliza químicos, no utiliza azadón, poco líquido, barreras vivas, reforestación y levanta la basura inorgánica. Venta $(V E)$ : polvo, pergamino, seco y cereza.

A cada una de las formas en que realiza cada práctica se asignó un "Si", si realizaba la actividad y un "No", si no la realizaba. $\mathrm{Si}=2$ y $\mathrm{No}=1$.

Variable Superficie de Café. Es el número de hectáreas (ha) que el productor destina para producir café.

Variable Número de Cortadores con Pago: Se calculó mediante el número total de cortadores, menos aquellos sin pago.

También se utilizaron variables de segundo orden para caracterizar y tipificar a los productores: tenencia de la tierra, material del techo de la vivienda, número de actividades económicas, años de experiencia en el cultivo, práctica de la tradicional "viuda”, motivos para producir café, disposición a abandonar el cultivo de

$$
I C=I T-G V+G F
$$

where IT: Total Income, GV: Household Expenses, GF: Plantation Expenses.

Technological Index Variable. It was obtained from the sum of the practices carried out of cleaning, fertilization, digging holes, pruning, shade regulation, soil conservation practices, and sale. For its calculation, the following equation was considered:

$$
I T=L I+F E+A H+P O+R S+P C S+V E
$$

where Cleaning $(L I)$ : weeding with machete, with mattock, with weeding machine, and with liquid. Fertilization $(F E)$ : organic, chemical and lime. Digging holes $(A H)$ : hole-digger, driller, claw, tlalacha, digger, pick, hoe, shovel, spade, and digging stick. Pruning $(P O)$ : machete, chainsaw, serrote, scissors and hook. Shade regulation (RS): planting trees, pruning, knocking down dry trees, tree felling, inga jinicuil sowing, and grow on their own. Soil conservation practices (PCS): weeding not at level, sowing cane grass, not using chemicals, not using hoe, scarce liquid, live fences, reforestation and picking up inorganic garbage. Sale $(V E)$ : dust, parchment, dry and cherry.

Each one of the forms in which each practice is performed was assigned a "Yes", if the activity was carried out and a "No", if it was not carried out. Yes $=2$ and $\mathrm{No}_{\mathrm{O}}=1$.

Coffee Surface Variable. It is the number of hectares (ha) that the producer destines to producing coffee.

Number of Paid Cutters Variable. It was calculated through the total number of cutters, minus those without payment.

Variables of second order were also used to characterize and typify the producers: land ownership, material from roof to household, number of economic activities, years of experience with the crop, practice of the traditional "widow", reasons to produce coffee, willingness to abandon coffee cultivation, and changes in management of their coffee producing agroecosystems. Data analysis consisted in descriptive analysis, variance analysis, 
café y cambios en el manejo de sus agroecosistemas cafetaleros. El análisis de datos consistió en análisis descriptivo, análisis de varianza y tablas de frecuencia. Se llevó a cabo con el programa Statistica Versión 7.1.

\section{Resultados y Discusión}

\section{Características socioeconómicas}

En el DDR 005 de Fortín, Veracruz, de los productores cafetaleros entrevistados, $84.13 \%$ son del sexo masculino y $15.86 \%$ del femenino. La edad promedio de los productores de café es de 53 años. De acuerdo con Hernández (2006), Escamilla et al. (2005; 2012) y Benítez-García et al. (2015), la edad del cafeticultor está entre 49 y 56 años. La edad madura de estas personas se considera una limitante para transmitir las bondades de una práctica o técnica, que los hace más apegados a sus métodos tradicionales, por lo que los productores de la zona de estudio no están dispuestos a cambiar la forma en que producen su café. Estos resultados coinciden con los obtenidos por Ortega et al. (2010), quienes encontraron que $92 \%$ de sus entrevistados no estarían dispuestos a cambiar de cultivo pese a los bajos precios que el aromático presenta.

Por otra parte, la escolaridad de los entrevistados es de nivel básico. La media es de 5.64 años. Este dato coincide con Benítez-García et al. (2015), quienes reportaron una media de 5.6 ańos para productores cafetaleros del estado de Puebla. Incluso en la región estudiada, algunos de los entrevistados no tienen ningún grado de escolaridad. Sin embargo, ellos consideran que esto no es impedimento para dar un manejo mejor a su agroecosistema cafetalero. Incluso, algunos comentaron que el nivel de estudio no les ayuda a mejorar su producción; por lo que de haber estudiado estaría desempeñando actividades propias de los profesionistas.

Los productores de este Distrito tienen un rendimiento promedio de $4.04 \mathrm{t} \mathrm{ha}^{-1}$; los que más cosechan son los del municipio de Tomatlán con 5.87 $\mathrm{t} \mathrm{ha}^{-1}$, seguidos por los de Córdoba y de Huatusco (5.24 y $5.19 \mathrm{t} \mathrm{ha}^{-1}$, respectivamente). Los productores del municipio de Tlaltetela son los que poseen rendimientos menores $\left(2.61 \mathrm{t} \mathrm{ha}^{-1}\right)$; no obstante, el rendimiento de este último es superior a los $2.02 \mathrm{t}$ $\mathrm{ha}^{-1}$ que reporta el SIAP (2013) para este Distrito y al and frequency tables. It was performed with the software Statistica Version 7.1.

\section{Results AND Discussion}

\section{Socioeconomic characteristics}

In the DDR 005 of Fortín, Veracruz, among the coffee producers interviewed, $84.13 \%$ are men and $15.86 \%$ are women. The average age of the coffee producers is 53 years. According to Hernández (2006), Escamilla et al. $(2005 ; 2012)$ and BenítezGarcía et al. (2015), the age of the coffee producer is between 49 and 56 years. The mature age of these people is considered a limitation to transmit the favorable aspects of a practice or technique, which makes them more attached to their traditional methods, which is why producers in the study zone are not willing to change the way in which they produce their coffee. These results coincide with those obtained by Ortega et al. (2010), who found that $92 \%$ of their interview respondents were not willing to change crop despite the low prices that the aromatic presents.

On the other hand, schooling of interview respondents is of basic level. The mean is 5.64 years. This piece of data coincides with Benítez-García et al. (2015), who reported a mean of 5.6 years for coffee producers of the state of Puebla. Even in the region studied, some of the interview respondents do not have any degree of schooling. However, they consider that this is not an obstacle to manage better their coffee producing agroecosystem. In fact, some mentioned that the level of study does not help them to improve their production, which is why having studied they would be carrying out activities that professionals do.

The producers of this District have an average yield of $4.04 \mathrm{t} \mathrm{ha}^{-1}$; the ones that harvest most are those from the municipality of Tomatlán with $5.87 \mathrm{t}$ $\mathrm{ha}^{-1}$, followed by those from Córdoba and Huatusco (5.24 and $5.19 \mathrm{t} \mathrm{ha}^{-1}$, respectively). Producers from the municipality of Tlaltetela are the ones that have lowest yields $\left(2.61 \mathrm{t} \mathrm{ha}^{-1}\right)$; however, the yield of the latter is higher than the $2.02 \mathrm{t} \mathrm{ha}^{-1}$ that SIAP (2013) reports for this District and the national average, of 1.92 tons per hectare. The differences between production and yield of coffee plantations depends, in addition to the weather, on the technological 
promedio nacional, de 1.92 toneladas por hectárea. Las diferencias entre la producción y el rendimiento de los cafetales depende, además del clima, del nivel tecnológico, así como del tipo, forma de aplicación de sus prácticas agrícolas y escala de producción (Castillo, 2013).

El $97.24 \%$ de estos productores venden su café en cereza y de este porcentaje $6.20 \%$ lo vende además en pergamino o seco. Martínez (2012) menciona que estas acciones ocasionan que los productores permanezcan a merced de las empresas comercializadoras trasnacionales implementadas en la región, siendo AMSA y NESTLÉ las grandes acaparadoras; a quienes Martínez (2012) les atribuye la inestabilidad en el precio del café, debido a que la venta para llegar a ellas se realiza a través de intermediarios locales.

\section{Tipos de productores}

En este Distrito se identificaron tres tipos de productores: de subsistencia, transicional y empresarial a partir de un análisis de conglomerados, y posteriormente se aplicaron análisis de varianza.

De esta manera, analizando la variable "ingreso capitalizable" se encontraron diferencias estadísticas entre los tres tipos de productores identificados $(\mathrm{p}=0.00001)$ (Figura 1); los de subsistencia con ingresos capitalizables menores a 30000 pesos en el ciclo, los de tipo transicional de 30000.00 a 110000 pesos, y los de tipo empresarial de 110000.00 pesos en adelante, siendo los de tipo empresarial los de mayor acceso a capitalizar sus ingresos, resultados que coinciden con Bacon y Guharay (2011) y Rizzo (2012) al indicar que a estos productores les alcanza su ingreso para capitalizar, contrario a los de subsistencia, cuyos ingresos alcanzan apenas para solventar sus necesidades básicas.

A pesar de que Bacon y Guharay (2011) y Rizzo (2012) aportan una tipología de productores, en ella solo identifican a los de tipo empresarial y de subsistencia, ubicando a la agricultura empresarial como la dirigida al mercado, como monocultivo, con uso de agroquímicos e insecticidas sintéticos para las plagas. Estas tipologías son importantes en análisis; sin embargo, difieren en estrato, debido a que ellos solo clasifican a dos tipos de productores, contrario a esta investigación que aporta un estrato más, el tipo transicional, quienes son los productores de subsistencia level, as well as the type, form of application of their agricultural practices and scale of production (Castillo, 2013).

Of these producers, $97.24 \%$ sell their coffee in cherry and of this percentage, $6.20 \%$ also sell it in parchment or dry. Martínez (2012) mentions that these actions cause for producers to remain at the mercy of the transnational trading companies implemented in the region, with AMSA and NESTLÉ being the large hoarders, to which Martínez (2012) attributes the instability in coffee prices, because the sale to reach these is carried out through local intermediaries.

\section{Types of producers}

In this District, three types of producers were identified: subsistence, transitional and entrepreneurial, based on the analysis of conglomerates, and variance analyses were applied later.

In this way, analyzing the variable "capitalized income" statistical differences were found between the three types of producers identified $(\mathrm{p}=0.00001)$ (Figure 1); the subsistence ones with capitalized income below 30000 pesos in the cycle, the transitional with 30000 to 110000 pesos, and the entrepreneurial with 110000 pesos and more, with the entrepreneurial being the ones with greatest access to capitalizing their income, results that coincide with Bacon and Guharay (2011) and Rizzo (2012) by

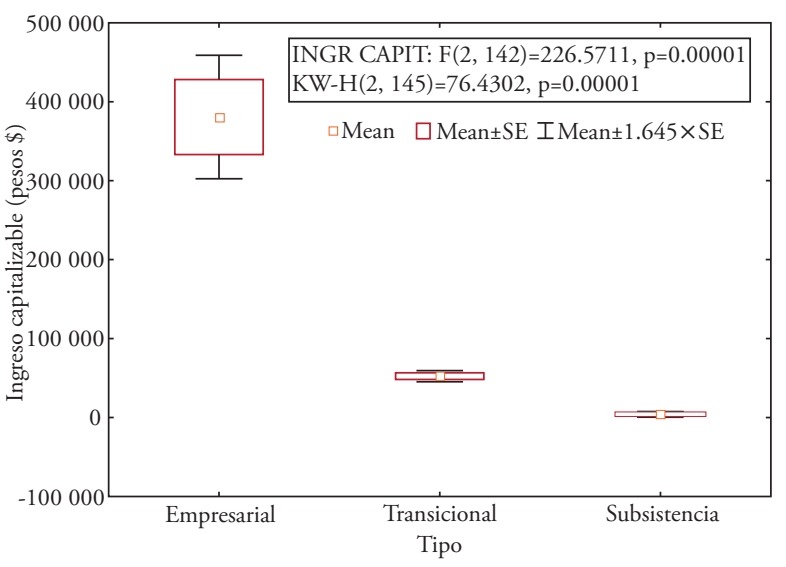

Figura 1. Tipos de productores cafetaleros por ingreso capitalizable.

Figure 1. Types of coffee producers per capitalized income. 
en vía a la empresarialidad o, en caso contrario, pueden retroceder al de subsistencia.

$\mathrm{Al}$ analizar la variable "nivel tecnológico" también se observan diferencias significativas $(\mathrm{p}=0.00001)$. Los de tipo de subsistencia presentan menor nivel tecnológico que los de tipo transicional y empresarial (Figura 2), lo cual se ve reflejado en el tipo de herramientas que utilizan para realizar las prácticas de manejo en sus fincas cafetaleras. En algún momento en México esta tecnificación de los cafetales se fomentó a través de las políticas agrarias e instituciones como el INMECAFE con el objetivo de impulsar la productividad haciendo uso de insumos externos, como variedades especializadas o genéticamente modificadas, como monocultivos, aplicación de fertilizantes inorgánicos etcétera, que a su vez produjeron cambios drásticos en la naturaleza del cultivo. El nivel tecnológico de cada productor puede estar relacionado con factores como el rendimiento por hectárea y la extensión de superficie utilizada; sin embargo, cuando son extensiones de producción mayores se utiliza tecnología moderna, con mentalidad empresarial, se da agregación de valor al producto y se mejora la competitividad, buscando siempre mayor rentabilidad (Salinas, 2004; Benítez-García et al., 2015).

Por otra parte, al analizar la variable "superficie de café" también se obtuvieron tres tipos de productores, el de subsistencia (menos de $5 \mathrm{ha}$ ), de tipo transicional (de seis a $20 \mathrm{ha}$ ) y de tipo empresarial (de 21 a $63 \mathrm{ha}$ ); se presentaron diferencias

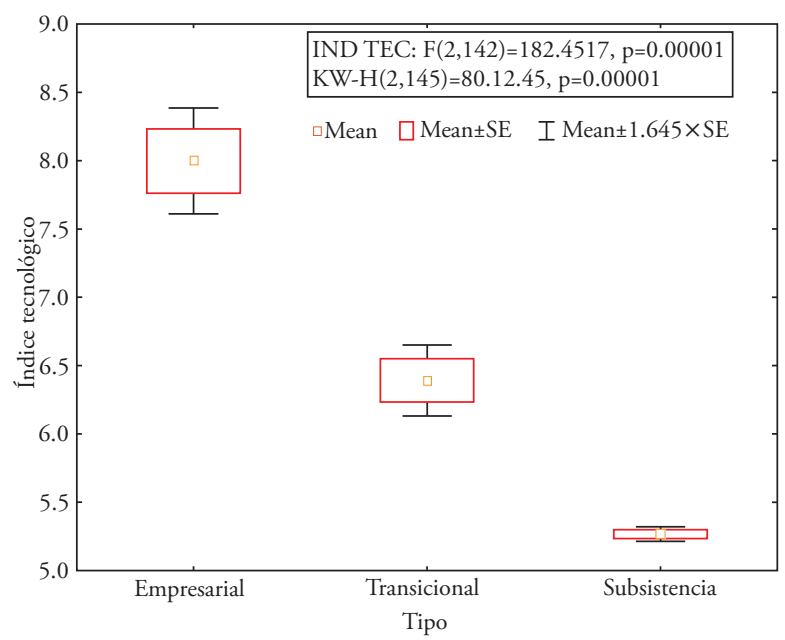

Figura 2. Tipo de productores por nivel tecnológico. Figure 2. Type of producers per technological level. indicating that these producers have enough income to capitalize, contrary to the subsistence ones, whose income is barely enough to afford their basic needs.

Although Bacon and Guharay (2011) and Rizzo (2012) contribute a typology of producers, they only identify those of entrepreneurial and subsistence type in it, placing entrepreneurial agriculture as the one directed at the market, such as monoculture with use of agrochemicals and synthetic insecticides for pests. These typologies are important in the analysis; however, they differ in stratum because they only classify two types of producers, contrary to this study which contributes a further stratum, the transitional type, which are subsistence producers on the pathway to entrepreneurship or, in contrast, returning to subsistence.

When analyzing the "technological level" variable significant differences are also observed $(p=0.00001)$. Those of subsistence type present lower technological level than those of transitional and entrepreneurial type (Figure 2), which is reflected in the type of tools they use to carry out management practices in their coffee plantations. At some point in México this technification of coffee plantations was promoted through agrarian policies and institutions like INMECAFE with the objective of driving productivity making use of external inputs, such as specialized or genetically modified varieties, like monocrops, application of inorganic fertilizers, etc., which in turn produced drastic changes in the nature

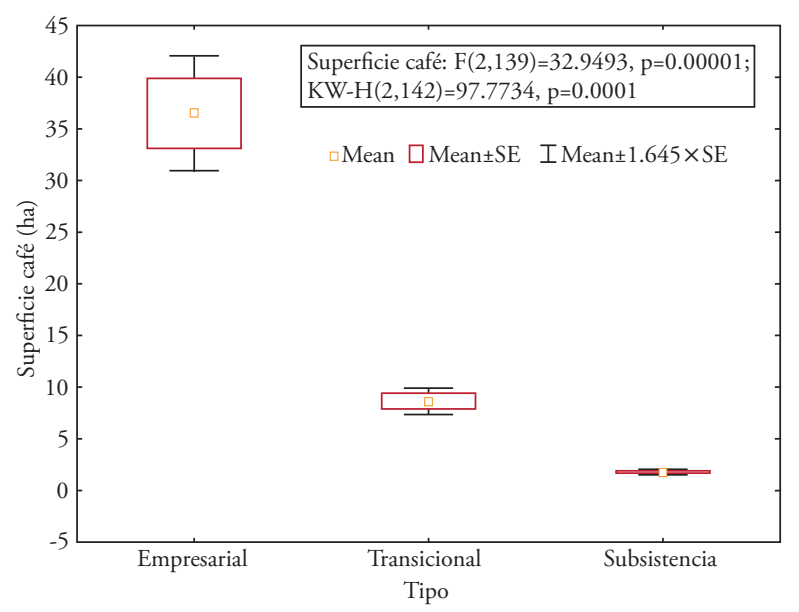

Figura 3. Tipo de productor por superficie de café. Figure 3. Type of producer per coffee surface. 
estadísticas significativas entre ellos $(\mathrm{p}=00.00001)$ (Figura 3). Macip (2007) menciona que los productores del nivel más bajo poseen tierras pequeñas de cultivo trabajadas por él mismo y solo contrata fuerza de trabajo con poca frecuencia en la época de siembra y cosecha; asimismo, suele vender su fuerza de trabajo durante el periodo de "trabajo muerto", es decir, en aquellos días en que su tierra no demanda mucha fuerza de trabajo, contrario a lo que sucede con los del nivel más alto (empresarial). Damián et al. (2011) reportó que productores maiceros con mayor superficie utilizan mejor tecnología y, por lo tanto, generan mayor rendimiento.

$\mathrm{Al}$ analizar la variable "cortadores con pago", de la misma manera se observan diferencias significativas $(\mathrm{p}=00.00001)$ entre los productores de subsistencia, transicionales y empresariales (Figura 4). $\mathrm{La}$ fase de cosecha es la que requiere mayor demanda de trabajadores; sin embargo, es lenta y origina mayor convivencia familiar (Vázquez, 2010). Para ella, los productores de tipo empresarial contratan mayor número de cortadores (30 a 150) que los de subsistencia ( 0 a 11 ), ubicando a los de tipo transicional entre estos dos tipos. De acuerdo con las opiniones de los entrevistados, la mano de obra calificada ha presentado reducciones debido a que se ha sustituido por maquinaria; tan solo en prácticas de limpia, si antes se realizaba el chapeo con machete, ahora se utiliza la chapeadora, con lo que se eficientiza el trabajo.

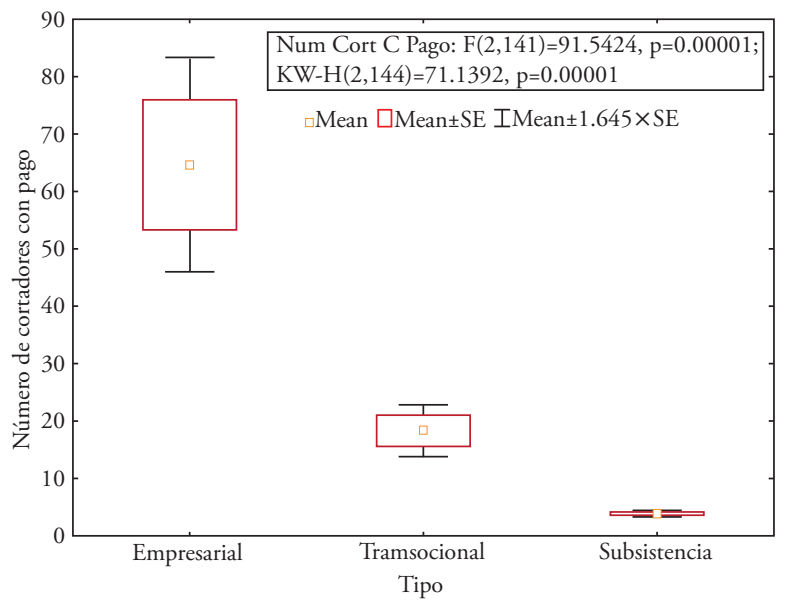

Figura 4. Tipo de productor por número de cortadores con pago.

Figure 4. Type of producer per number of paid cutters. of the crop. The technological level of each producer can be related to factors such as yield per hectare and the extension of the surface used; however, when the production areas are larger, modern technology is used, with entrepreneurial mentality, value is added for the product and competitiveness is improved, always seeking higher profitability (Salinas, 2004; Benítez-García et al., 2015).

On the other hand, when analyzing the variable "surface of coffee", three types of producers were also obtained: subsistence (less than 5 ha), transitional (six to $20 \mathrm{ha}$ ), and entrepreneurial (21 to $63 \mathrm{ha}$ ); significant statistical differences were found between them ( $p=00.00001) \quad$ (Figure 3). Macip (2007) mentions that producers of the lowest level have small cultivation lands farmed by themselves and only hire workforce few times during sowing and harvesting time; likewise, they tend to sell their labor during the period of "dead work", that is, on those days when their land does not demand much labor, contrary to what happens with those of higher level (entrepreneurial). Damián et al. (2011) reported that maize producers with larger surface use better technology and, therefore, generate higher yield.

When analyzing the variable "paid cutters", in the same way, significant differences are observed $(p=00.00001)$ between subsistence, transitional and entrepreneurial producers (Figure 4). The harvesting phase is the one that requires greater demand of workers; however, it is slow and originates greater family cohabitation (Vázquez, 2010). For this purpose, producers of entrepreneurial type hire a higher number of cutters (30 to 150) than those of subsistence type (0 to 11$)$, locating the transitional type between these two types. According to the opinions of the interview respondents, qualified labor has shown reductions because it has been substituted by machinery; just in cleaning practices, when weeding used to be done with machete, now the weeding machine is used, with which the work is made more efficient.

Rodríguez and Castro (2012) mention that in order to avoid this substitution of unqualified work by machines, it is necessary for the cost of unqualified labor expressed in efficiency units not to exceed the cost of capital, which in recent decades has shown a permanent reduction, since the greater use of technology and its complementarity with qualified work have an influence on the productivity of this 
Rodríguez y Castro (2012) mencionan que para evitar esta sustitución de trabajo no calificado por maquinaria es necesario que el costo de mano de obra no calificada expresado en unidades de eficiencia no supere al del capital, mismo que las últimas décadas ha mostrado una reducción permanente. Ya que la mayor utilización de tecnología y su complementariedad con el trabajo calificado inciden sobre la productividad de este tipo de mano de obra al verse disminuido en las prácticas del cultivo.

La distribución de estos tres tipos de productores cafetaleros dentro del DDR 005 de Fortín se da de la siguiente manera: en los municipios de Huatusco, Totutla y Comapa se encuentra el mayor porcentaje de productores cafetaleros de tipo empresarial (seis, cuatro y cuatro productores, respectivamente) y en los municipios como Totutla, Comapa y Tenampa se encuentra el mayor número de productores de subsistencia (29, 13 y 12 productores, respectivamente). Por su parte, los de tipo transicional están ubicados en Totutla y Comapa (ocho y siete, respectivamente) (Cuadro 1). Además, se observó que la mayoría de los productores de tipo empresarial son descendientes de italianos o alemanes inmigrantes; Tarrío y Concheiro (2006) lo confirman al reportar que desde 1927 en Huatusco y Zentla había un elevado porcentaje de la población que era descendiente de inmigrantes, donde $73.4 \%$ de los finqueros dedicados a la producción de café eran extranjeros, siendo $34 \%$ de ellos alemanes. type of labor when it is decreased in the cultivation practices.

The distribution of these three types of coffee producers in the DDR 005 Fortín takes place in the following way: in the municipalities of Huatusco, Totutla and Comapa we find the highest percentage of coffee producers of entrepreneurial type (six, four and four producers, respectively), and in municipalities like Totutla, Comapa and Tenampa the highest number of subsistence producers are found (29, 13 and 12 producers, respectively). In their turn, those of transitional type are located in Totutla and Comapa (eight and seven, respectively) (Table 1). In addition, it was observed that most of the producers of entrepreneurial type are descendants from Italian or German migrants; Tarrío and Concheiro (2006) confirmed this, when reporting that since 1927 there was a high percentage of the population that was descendant of migrants in Huatusco and Zentla, where $73.4 \%$ of the plantation owners devoted to coffee production were foreigners, with $34 \%$ of them being German.

\section{Types of coffee producers according to sociocultural aspects in the DDR 005 Fortín, Veracruz, México}

The variety of productive practices in plantations are related to the specific modes of conceiving coffee, where the forms of thought and practice

Cuadro 1. Tipos de productores cafetaleros por Municipio del DDR 005 Fortín, Veracruz, México. Table 1. Types of coffee producers per Municipality of the DDR 005 Fortín, Veracruz, México.

\begin{tabular}{lcccc}
\hline \multirow{2}{*}{ Municipio } & & Tipo de productor & & $\begin{array}{c}\text { Total por } \\
\text { municipio }\end{array}$ \\
\cline { 2 - 5 } & Subsistencia & Transicional & Empresarial & 24 \\
Comapa & 13 & 7 & 4 & 14 \\
Huatusco & 6 & 2 & 6 & 12 \\
Ixhuatlán & 11 & 1 & 0 & 41 \\
Totutla & 29 & 8 & 4 & 4 \\
Tepatlaxco & 2 & 1 & 1 & 11 \\
Tlacotepec & 10 & 1 & 0 & 5 \\
Zentla & 2 & 2 & 1 & 3 \\
Córdoba & 1 & 2 & 0 & 1 \\
Chocamán & 0 & 1 & 1 & 7 \\
Tlaltetela & 6 & 0 & 0 & 14 \\
Tenampa & 12 & 2 & 0 & 4 \\
Tomatlán & 3 & 1 & 0 & 5 \\
Sochiapa & 3 & 2 & 17 & 145 \\
\hline Total por tipo & 98 & 30 & & \\
\hline
\end{tabular}




\section{Tipos de productores cafetaleros de acuerdo a aspectos culturo-sociales en el DDR 005 Fortín, Veracruz, México}

La variedad de prácticas productivas en las fincas se relaciona con los modos específicos de concebir el café, donde las formas de pensamiento y de práctica se han ido construyendo socialmente en el marco de un contexto histórico-social, local y regional, a partir de la experiencia y la posición de los productores en la cadena productiva (Ejea, 2009). La apropiación del cultivo de café ha generado una gran riqueza de conocimientos y adaptaciones para su manejo importantes de valorar (Bolaños y González, 2008). Toda práctica económica o productiva, como lo es la de cultivar café y organizar el trabajo en torno a ello, conlleva implícitamente una dimensión cultural, entendida esta como asignación de sentido. Gracias a esta cultura, los campesinos incorporan el café a su vida social y productiva de diversos modos, no de uno solo, aun cuando se trata de pequeńos productores que comparten condiciones de producción semejantes, por lo que es importante ubicarse en las dinámicas locales, las de cada poblado, dentro de la región y en la relación que los productores y sus familias establecen con el producto (Ejea, 2009).

Dado lo anterior, se analiza una variable incluida dentro de las prácticas tradicionales que conservan los productores cafetaleros en su finca, la tradicional "viuda", la cual consiste en una comida que el productor ofrece a sus cortadores al finalizar la temporada de cosecha; esto como una forma de agradecimiento y generar la convivencia entre sus familiares, sus trabajadores y todos los que participan en el proceso de producción, principalmente en la fase de corte. En el Cuadro 2 se observa que son los productores de tipo empresarial los que más conservan y practican esta tradición, y los de subsistencia los que menos la practican. De acuerdo con cómo asciende el tipo de productor, también lo hace el porcentaje del número de productores que realizan esta práctica. Esto explica que la mayoría de los productores de subsistencia poseen terrenos pequeños para cultivar café y no contratan mayor porcentaje de mano de obra con pago, e incluso en ocasiones es nula, y las personas que apoyan al productor son en su mayoría familiares que no reciben pago alguno por sus actividades.

Con respecto a la fortaleza cultural del cultivo de café por tipo (subsistencia, transicional y empresarial), have been building socially within the framework of a historical-social, local and regional, context from the experience and position of producers in the productive chain (Ejea, 2009). The appropriation of the coffee crop has generated a great wealth of knowledge and adaptations for its management that are important to be valued (Bolaños and González, 2008). All economic and productive practice, such as cultivating coffee and organizing work around it, implicitly implies a cultural dimension, understood as an allocation of meaning. Thanks to this culture, peasants incorporate coffee into their social and productive life in various ways, not just in a single one, even when it is small-scale producers who share similar production conditions, which is why it is important to be positioned in the local dynamics, those of each town within the region, and in the relationship that the producers and their families establish with the product (Ejea, 2009).

Given this, a variable included within traditional practices that coffee producers conserve in their plantations is analyzed, the traditional "widow", which consists of a meal that the producer offers his cutters at the end of the harvesting season; this is used as a way of thanking and generating coexistence between family members, workers and everyone who participates in the production process, primarily during the cutting phase. Table 2 shows that it is entrepreneurial producers who conserve and practice this tradition most, and the subsistence ones who practice it less. According to the how the type of producer ascends, so does the percentage of number of producers who carry out this practice. This explains that most of the subsistence producers have small plots to cultivate coffee and do not hire a greater percentage of paid labor, and in fact sometimes they do not, and the people who support the producer are mostly relatives who do not receive any pay for their activities.

With regard to the cultural strength of coffee cultivation per type (subsistence, transitional and entrepreneurial), the percentages of those who would be willing to cease producing coffee and the ones who would not are somewhat similar (Yes $=78.57 \%$, $70 \%, 76.47 \%$; No=21.43\%, $30 \%, 23.53 \%)$ (Table 2). These results lead to defining that the type of producer does not matter in the preservation of the coffee producing culture, which, as Ortega et al. (2010) mention, continues to be rooted among their 
Cuadro 2. Tipos de productores de acuerdo a variables culturo-sociales. Table 2. Types of producers according to sociocultural variables.

\begin{tabular}{|c|c|c|c|c|c|c|}
\hline \multirow{3}{*}{ Variables } & \multicolumn{6}{|c|}{ Tipos de productores cafetaleros } \\
\hline & \multicolumn{2}{|c|}{ Bajo } & \multicolumn{2}{|c|}{ Medio } & \multicolumn{2}{|c|}{ Alto } \\
\hline & $\mathrm{Si}$ & No & $\mathrm{Si}$ & No & $\mathrm{Si}$ & No \\
\hline Práctica tradicional de la "viuda" (\%) & 64.29 & 35.71 & 33 & 66.67 & 5.88 & 94.12 \\
\hline Disponibilidad para dejar de producir café (\%) & 76.47 & 23.53 & 70 & 30.00 & 78.57 & 21.43 \\
\hline Disponibilidad para recibir capacitación (\%) & 39.80 & 60.20 & 40 & 60.00 & 35.29 & 64.71 \\
\hline
\end{tabular}

los porcentajes entre los que sí estarían dispuestos a dejar de producir café y los que no son un tanto similares $(\mathrm{Si}=78.57 \%, 70 \%, 76.47 \%$; $\mathrm{No}=21.43 \%$, $30 \%, 23.53 \%$ ) (Cuadro 2). Estos resultados conducen a determinar que no importa el tipo de productor en la preservación de la cultura del cultivo de café, la cual, como mencionan Ortega et al. (2010), continúa arraigada entre sus generaciones. Estos productores comentaron estar dispuestos a dejar de producir el aromático, con la condición de tener la alternativa de otro cultivo que les genere mejores ingresos económicos. El 23.45 \% manifestó no abandonar el cultivo pese a las malas situaciones presentadas, como bajos precios, debido a que cultivan más por la tradición heredada por sus padres y por gusto que por la obtención de ganancias económicas, por lo que la generación de ingresos económicos no es lo más importante para ellos. Ortega et al. (2010) encontraron que $92 \%$ de los productores cafetaleros entrevistados en Huehuetla, Puebla seguirían dedicados al cultivo de café, independientemente de los precios del grano. Ante la posibilidad de que sucedan o no estos cambios, Perea y Rivas (2008) explican y evidencian la dificultad para convencer a la gente a ello cuando se han acostumbrado a cierta forma de vida que les permite resolver sus problemas.

De la misma manera, más de $60 \%$ de los productores entrevistados están a favor de recibir capacitación para el manejo de sus fincas cafetaleras; ellos consideran esta capacitación como un beneficio para sus producciones, toda vez que quien las imparta muestre experiencia y capacidades superiores a los suyos. La capacitación a productores en México está dada en $70.8 \%$ por técnicos, $17.7 \%$ por productores, $2.8 \%$ por instituciones académicas o de investigación, y $1.5 \%$ otorgado por despachos (Cuevas et al., 2012). No obstante, estos mismos autores aseguran que la cobertura de asistencia técnica es baja; $3 \%$ del total nacional de unidades de producción con actividad agropecuaria disponen de este servicio. generations. These producers mentioned that they are willing to stop producing the aromatic species, with the condition of having the alternative of another crop that generates higher economic income. A percentage of $23.45 \%$ manifested not abandoning the crop despite the bad situations present, such as low prices, because they cultivate it more because of the tradition inherited from their parents and because of the joy of it than in order to obtain economic profit, so that the generation of financial income is not the most important element for them. Ortega et al. (2010) found that $92 \%$ of the coffee producers interviewed in Huehuetla, Puebla, would continue to be devoted to coffee production, regardless of the grain prices. Facing the possibility of these changes taking place or not, Perea and Rivas (2008) explain and make evident the difficulty in convincing people of it when they have grown accustomed to a certain lifestyle that allows them to solve their problems.

Similarly, more than $60 \%$ of the producers interviewed are in favor of receiving training for the management of their coffee plantations; they consider this training as a benefit for their production, insofar as the person who offers it can show experience and higher capacities than theirs. Training for producers in México is offered in $70.8 \%$ by technicians, $17.7 \%$ by producers, $2.8 \%$ by academic and research institutions, and $1.5 \%$ by firms (Cuevas et al., 2012). However, the same authors state that the coverage of technical assistance is low; $3 \%$ of the national total of production units with agricultural and livestock activity have this service. Despite this deficiency, at the sector level, agriculture has a higher coverage of technical assistance (75\%), compared to the livestock sector, with $19.3 \%$, to the forestry sector with $3.2 \%$, and $2.5 \%$ for another sector.

On the other hand, land ownership of subsistence coffee producers happens in the following percentages: $1.03 \%$ rented, $26.53 \%$ ejidal, $60.20 \%$ private, $2.04 \%$ private-federal, and $10.20 \%$ private-ejidal. 
Pese a esta deficiencia, a nivel sector, la agricultura cuenta con la mayor cobertura de asistencia técnica (75\%), a diferencia del sector pecuario, con $19.3 \%$, del sector forestal, con $3.2 \%$, y $2.5 \%$ en otro sector.

Por otra parte, la tenencia de la tierra de los productores cafetaleros de subsistencia se da en los siguientes porcentajes: $1.03 \%$ rentada, $26.53 \%$ ejidal, $60.20 \%$ privada, $2.04 \%$ privada-federal, y $10.20 \%$ es privada-ejidal. Para los de tipo transicional, $6.67 \%$ es ejidal; $80 \%$, privada; $3.33 \%$, privada-rentada; y $10 \%$, privada-ejidal. Para los de tipo empresarial, $0.69 \%$ es rentada; $5.19 \%$, ejidal; y $94.12 \%$, privada. Ante esto, se observa que los productores de tipo empresarial son los que poseen más tierras privadas y que los de subsistencia son los que poseen más del tipo ejidal. Tarrío y Concheiro (2006) mencionan que los ejidatarios son producto de las dotaciones de tierras otorgadas a la población campesina del país a partir de la Revolución de 1910. No obstante, Ibarra y Morales (1999) no encuentran diferencias entre estos tipos de tenencia de tierra; ellos afirman que la mayor parte de los propietarios privados se encuentra en una situación económica y social igual o más desfavorable que los ejidatarios comuneros; empero, la percepción que se tuvo de este último tipo en esta investigación fue contraria a lo que mencionan estos autores, observando menor calidad de vida en los productores con tierra de tipo ejidal que aquellos con tierras privadas, aspectos sobresalientes, por ejemplo, en el tipo de vivienda que poseen y algunos otros bienes materiales como autos o algún negocio.

\section{Conclusiones}

En el Distrito 005 de Fortín, Veracruz, México existen tres tipos de productores cafetaleros: de subsistencia, transicional y empresarial, donde cada uno de ellos se caracteriza por poseer rasgos altamente diferenciados, aspectos sobre de todo de tipo productivo y culturo-social. Los de tipo empresarial poseen mayor superficie dedicada al cultivo, mayor nivel tecnológico, mayor número de cortadores con pago y mayor ingreso capitalizable. Los productores de tipo transicional poseen los valores medios en las variables anteriormente mencionadas. Esta investigación evidencia que la superficie sembrada del cultivo está relacionada con el nivel tecnológico, el ingreso capitalizable y los cortadores con pago, por lo que comprendimos que estas variables son importantes para definir los distintos tipos de productores cafetaleros.
For the transitional type, $6.67 \%$ is ejidal; $80 \%$, private; $3.33 \%$, private-rented; and $10 \%$, privateejidal. For the entrepreneurial type, $0.69 \%$ is rented; $5.19 \%$, ejidal; and $94.12 \%$, private. Given this, it is observed that producers of the entrepreneurial type are the ones that have more private lands and that subsistence producers are the ones that have more land of ejidal type. Tarrío and Concheiro (2006) mention that the ejidatarios are product of land endowment given to the peasant population in the country, as a result of the 1910 Revolution. However, Ibarra and Morales (1999) do not find differences between these types of land ownership; they say that most of the private owners are in an economic and social situation equal to or more unfavorable than communal ejidatarios; however, the perception of this last type in this study was opposite to what these authors mention, finding a lower quality of life in producers with lands of ejidal type than those with private lands, outstanding aspect, for example, in the type of housing they have and some other material goods such as cars and businesses.

\section{Conclusions}

In the District 005 of Fortín, Veracruz, México, there are three types of coffee producers: subsistence, transitional and entrepreneurial, where each one of them is characterized by having highly differentiated characteristics, aspects particularly of productive and sociocultural type. Producers of entrepreneurial type have greater surface devoted to the crop, higher technological level, higher number of paid cutters, and higher capitalized income. The transitional type producers have average values in the variables mentioned before. This study evidences that the surface sown with the crop is related to the technological level, capitalized income, and paid cutters, so it was understood that these variables are important to define the different types of coffee producers.

The three types of producers have the same cultural practices and are not willing to stop producing coffee. They have a similar attitude toward receiving training. The reason why subsistence producers do not carry out the traditional "widow" lies in that they have a smaller surface of coffee than in the two types of peasants (subsistence and transitional) and they do not have the need to hire a greater number of paid 
Los tres tipos de productores poseen las mismas prácticas culturales y no están dispuestos a dejar de producir café. Poseen actitud similar para recibir capacitación. La razón de que los productores de subsistencia no realicen la tradicional "viuda" radica en que poseen menor superficie de café que en los dos tipos campesinos (el de subsistencia y el transicional) y no tienen la necesidad de contratar mayor número de cortadores con pago, como en el caso de los productores de tipo empresarial. Lo anterior permite entender que esta práctica podría considerarse una tradición de agricultores y no campesinos.

En este mismo sentido, en este Distrito, el cultivo del café, como el de los demás cultivos importantes, por su carácter tradicional, ha representado una opción de subsistencia y reproducción social más que para la acumulación de riquezas o de capital con alta productividad económica, por lo que existe la urgencia de diseñar e implementar estrategias que permitan a los cafetaleros de todos los niveles a continuar con la reproducción de sus agroecosistemas cafetaleros y reducir su vulnerabilidad ante situaciones impredecibles, como la caída de los precios internacionales del café, así como contingencias ambientales y de sanidad vegetal, ampliando la complejidad de su vivir.

\section{Agradecimientos}

Los autores (as) agradecen al Consejo Nacional de Ciencia y Tecnología (CONACyT) por la beca otorgada para los estudios doctorales del primer autor, de los cuales se desprende esta investigación y al Colegio de Postgraduados por el Fideicomiso Revocable No. 167304 por el financiamiento otorgado.

\section{Literatura Citada}

Bacon, Cristopher y Guharay Falguni. 2011. En busca de alianzas en zonas cafetaleras de Nicaragua. Foro Prácticas y Estrategias para la Seguridad y Soberanía Alimentaria en Zonas Cafetaleras de Nicaragua, Matagalpa. Ed. Ediciones Educativas.

Benítez-García, Érika, Jaramillo-Villanueva, José L., EscobedoGarrido, Sergio, y Mora-Flores, Saturnino. 2015. Caracterización de la producción y del comercio de café en el municipio de Cuetzalan, Puebla. Agricultura, Sociedad y Desarrollo 12:181-198.

Bolaños, Mario. 1999. Caracterización y tipificación de organizaciones de productores y productoras. XI Congreso Nacional Agronómico y I Congreso Nacional de Extensión. pp: 31-39.

Bolaños, Mario y González Álvaro. 2008. Café orgánico de sombra en el Rincón de Ixtlán, Oaxaca, México. [En línea]. Cali, Colombia. www.agroforesteríaecologica.com (Noviembre, 2008). cutters, as is the case of producers of entrepreneurial type. This allows understanding that this practice could be considered a tradition of farmers and not of peasants.

In this same sense, in this District, coffee cultivation, as that of other important crops has represented an option for subsistence and social reproduction rather than for the accumulation of wealth or capital with high economic productivity, because of its traditional nature, so there is an urgency to design and implement strategies that allow coffee producers of all levels to continue with the reproduction of their coffee agroecosystems and to reduce their vulnerability in face of unpredictable situations, such as the fall in international coffee prices, as well as environmental and plant health contingencies, broadening the complexity of their existence.

\section{AKNowledgements}

The authors thank the Consejo Nacional de Ciencia y Tecnología (CONACyT) for the scholarship granted for the first author's doctoral studies, on which this study is based, and Colegio de Postgraduados for the funding granted through the Fideicomiso Revocable No. 167304.

- End of the English version -

Castillo, Jorge. 2013. Intolerancia Diario: Queremos ver a Puebla en Segundo lugar de Producción de café. [Fecha de Publicación: 04 de agosto de 2013, (fecha de consulta: 13 de agosto de 2013. Disponible en http://www.intoleranciadiario.com/detalle_noticia.php?n=111424

CEPAL (Centro Económico para América Latina). 1989. Economía campesina y agricultura empresarial (tipología de productores del agro mexicano). Siglo XXI editores. México, D.F. pp: $95-114$.

Contreras, Armando. 2010. Los cafetales de Veracruz y su contribución a la sustentabilidad. Revista Estudios Agrarios: 143-161.

Cuevas, Venancio, Baca del Moral Julio, Fernando Cervantes, y José Aguilar A. 2012. Asistencia técnica en el sector agropecuario en México: análisis del VIII censo agropecuario y forestal. Revista Mexicana de Ciencias Agrícolas 3(5): 943-957.

Damián, Miguel Ángel, López Jesús Francisco, Ramírez Benito, Parra Filemón, Paredes Juan Alberto, Gil Abel y Cruz Artemio. 2011. Productividad y tenencia de la tierra: el caso de los productores de maíz del Estado de Tlaxcala, México. Cuadernos de Desarrollo Rural 4 (59): 149-177.

Ejea, María Teresa. 2009. Café y cultura productiva en una región de Veracruz. Documento de la Biblioteca Virtual del 
Instituto de Investigaciones Jurídicas de la UNAM. En www. juridicas.unam.mx (Junio, 2015).

Escamilla, Esteban, Ruiz Octavio, Díaz Gabriela, Landeros Cesáreo, Platas Diego Esteban, Zamarripa Alfredo, y González, Víctor A. 2005. El agroecosistema café orgánico en México. Manejo Integrado de Plagas y Agroecología 76:5-16.

Escamilla, Esteban, Escamilla Stephany, Gómez Juan Miguel, Tuxtla Monserrat, Ramos Julieta, y Pino José Manuel. 2012. Uso tradicional de tres especies de insectos comestibles en agroecosistemas cafetaleros del estado de Veracruz. Tropical and Subtropical Agroecosystems 15 (2): 101-109.

Gabriel, Josefina. 2003. Tipología socioeconómica de las actividades agrícolas, una herramienta de síntesis para el ordenamiento ecológico. INECOL-SEMARNAT. México, D.F. 49 p.

Hernández, Gerardo. 2006. Agroecosistemas cafetaleros de Veracruz. Clasificación agreocológica 15-34.

Ibarra, Roberto Francisco, y Morales Manuel. 1999. La propiedad privada rural. Revista Estudios Agrarios 12: 91-117.

INEGI (Instituto Nacional de Estadística y Geografía). 2009. Número y superficie total de unidades de producción según desarrollen o no actividad agropecuaria o forestal por entidad y municipio. Censo Agrícola, Ganadero y Forestal. http://www3.inegi.org.mx/sistemas/tabuladosbasicos/default.aspx?c=17177\&s=est (agosto, 2015).

LDRS (Ley de Desarrollo Rural Sustentable). 2001. Diario Oficial de la Federación, Secretaría de Agricultura, Ganadería, Desarrollo Rural, Pesca y Alimentación, México, 2001; 51 p.

Macip, Ricardo. 2007. Racismo y superexplotación: los jornaleros indígenas en el ejército industrial de reserva. Bajo el Volcán 7:45-60.

Madariaga, Marta Cecilia. 2001. Tipología de productores de la Cuenca del Arroyo Comallo-provincia de Río Negro. En Segundas Jornadas Interdisciplinarias de Estudios Agrarios y Agroindustriales. Universidad Nacional de Buenos Aires (UBA), Facultad de Ciencias Económicas, del 7 al 9 de noviembre.

Martínez, Miguel Ángel. 2012. Cambios estructurales en la economía cafetalera, en Del Valle, Carmen (coord), Crisis estructural y alternativas de desarrollo en México, IIEcUNAM.
Ortega, Alejandro, Ramírez Benito, Caso Laura, Ramírez Javier, Espinoza Gildardo, y Morett Jesús. 2010. Transformación de la estructura agraria en un municipio indígena productor de café en un contexto de crisis. Estudio de caso en Huehuetla, Puebla, México. Región y Sociedad XXII (48): 145-178.

Perea, Joaquín, y Rivas Luis Arturo. 2008. Estrategias competitivas para los productores cafetaleros de la región de Córdoba, Veracruz, frente al mercado mundial. Contaduría y Administración 224:9-33.

Rizzo, Nadia. 2012. Un análisis sobre la reproducción social como proceso significativo y como proceso desigual. Sociológica 27:281-297.

Rodríguez, Reyna Elizabeth, y Castro David. 2012. Efectos del cambio tecnológico en los mercados de trabajo regionales en México. Estudios Fronterizos, nueva época 13 (26): 141174.

Salinas, Edmar. 2004. El impacto de la onda cíclica de los precios del café en los productores de México. Análisis Económico XIX: 269-201.

Scheaffer L. Richard, Mendenhall William, y Ott Lyman. 1987. Elementos de muestreo. Grupo Editorial Ibero América, México, D. F. 320 p.

SIAP (Servicio de Información Agroalimentaria y Pesquera). 2013. En http://www.siap.gob.mx/ (Mayo, 2015).

Soverna, Susana, Tsakoumagkos Pedro, y Paz Raul. 2008. Revisando la definición de agricultura familiar. Proyecto PROINDER. SAGARPA. Serie documentos de capacitación No 7. Buenos Aires, 2008. 18 p.

Tarrío, María, y Concheiro Luciano. 2006. Chiapas: los cambios en la tenencia de la tierra. Argumentos UAM 19 (51): 31-71.

Toledo, Victor, Alarcón Pablo, y Barón Lourdes. 2002. La modernización rural de México: un análisis sociológico. Ed. SEMARNAT, INE-SEMARNAT, UNAM. $130 \mathrm{p}$.

Vázquez, Felipe. 2010. Impacto de los estilos de vida entre cafetaleros y cañeros en la vejez. Revista de Antropología Iberoamericana 5 (3): 430-446.

Vázquez, Ignacio, Vargas Samuel, Zaragoza José Luis, Bustamante Ángel, Calderón Francisco, Rojas Joel, y Casiano Miguel Ángel. 2009. Tipología de explotaciones ovinas en la sierra norte del estado de Puebla. Técnica Pecuaria México 47: 357-369. 